\title{
An analysis of farmers' buying behaviour and promotional activities for cumin seed in Junagadh district
}

See end of the paper for authors' affiliations

Correspondence to :

N.M. Thaker

P.G. Institute of AgriBusiness Management, Junagadh Agricultural University, Junagadh (Gujarat) India

Paper History :

Received : 31.01.2019;

Revised : 02.07.2019;

Accepted : 03.08.2019
ABSTRACT : Seed is the most important input component for productive agriculture. In the significant advances that India made in agriculture in the last four decades, the role of the seed sector has been substantial. The expansion of seed industry has occurred in parallel with growth in agricultural productivity. The organized seed industry of the country is just forty years old. Yet, its growth has been phenomenal. India is one of the few countries where the seed sector is already reasonably advanced. The private seed industry is no more confined to just production and marketing of seed. It has as well acquired technological strength to cater to the varietal needs of tomorrow. Cumin is grown as a Rabi crop in India and it is also grown well in sub-tropical climate, best suited for sandy soil. It requires less water and more cold for its better growth with ideal temperature of $25^{\circ}$ to $30^{\circ} \mathrm{C}$. Cumin crop is highly sensitive to rain, if rain occurs during harvesting time quality of the cumin will be badly affects besides quantity damage due to fungal diseases and cigarette beetle. It will turn black and will fetch the lowest price in the market. The present study is undertaken to the analysis of farmers' buying behaviour and promotional activities for cumin seed in Junagadh district, production constraints faced by farmers and finding effectiveness of promotional activities. Two tehsils were selected from purposively selected Junagadh district for the selection of respondents. From both the tehsil 100 farmers were selected randomly as per the availability.

KEY WORDS : Buying behaviour, Constraints, Promotional activities, Cumin

How To Cite This PAPer : Vagh, S.P., Thaker, N.M. and Bhatt, Jagruti D. (2019). An analysis of farmers' buying behaviour and promotional activities for cumin seed in Junagadh district. Internat. Res. J. Agric. Eco. \& Stat., 10 (2) : 186-193, DOI : 10.15740/HAS/IRJAES/10.2/186-193. Copyright@ 2019: Hind Agri-Horticultural Society. 